\title{
REFLEXÕES SOBRE A MÚSICA LITÚRGICA $^{1}$
}

\author{
Fernando Gianetti de Souza
}

Agente de Pastoral - Colégio Marista Arquidiocesano de São Paulo, Teólogo formado pelo Instituto de Teologia da Diocese de Santo André e integralizando o superior pela UMESP, São Paulo, SP - Brasil, e-mail: fgsouza@ marista.org.br

\section{Princípios gerais sobre a música litúrgica}

Segundo os documentos eclesiais, a música sacra não é algo secundário ou lateral na ação celebrativa da Igreja, mas é uma das expressões mais profundas e autênticas da própria liturgia e possibilita ao mesmo tempo uma participação pessoal e comunitária dos fiéis. Ela, como parte integrante da Liturgia solene, participa do seu fim geral que é a glória de Deus e a santificação dos fiéis. ${ }^{2}$ Ao indicar a importância e a necessidade do canto, a Igreja nos aponta a sua função:

- pelo canto, a oração se exprime com maior suavidade;

- mais claramente se manifestam o mistério da liturgia e sua índole hierárquica e comunitária;

- mais profundamente se atinge a unidade dos corações pela unidade das vozes;

- mais facilmente se elevam as almas pelo esplendor das coisas santas até as realidades supra terrenas;

- enfim, toda celebração mais claramente prefigura aquela efetuada na celestial Jerusalém. ${ }^{3}$

\footnotetext{
1 As sigla utilizadas no decorrer deste trabalho são: IV ENMS - IV Encontro Nacional de Música Sacra (1968). MS - Instrução da Sagrada Congregação dos Ritos sobre a Música na Sagrada Liturgia de 5/3/1967. SC - Constituição Sacrosanctum Concilium sobre a Liturgia, do Concílio Vaticano II (1963). TLS - Mótu próprio Tra le Sollecitudini de Pio X sobre a Música Sacra (1903). GS - Gaudium et Spes sobre a Igreja no mundo de hoje, do Concílio Vaticano II (1965). 2 TLS 1.

3 MS 5 e SC 112.
}

Rev. Pistis Prax., Teol. Pastor., Curitiba, v. 1, n. 1, p. 243-250, jan./jun. 2009 
A música, assim, está em íntima ligação com a liturgia, dela depende e a ela serve. Este serviço, que a Constituição conciliar chamou de "FUNÇÃO MINISTERIAL", como "feliz interpretação daquilo que a liturgia concebe, ${ }^{4}$ isto é, ser louvor de Deus em linguagem da comunidade em oração, requer certas normas que a música deve fazer suas, para atingir a função sacral" (PAULO VI, Discurso de 04/10/1965) e para corresponder à finalidade da ação litúrgica da Igreja, da qual esta música é parte integrante e necessária. ${ }^{5}$

Se a música for como de fato requer a liturgia, será um sinal que nos leva do visível ao invisível, um carisma que contribui para a edificação de toda a comunidade e a manifestação do mistério da Igreja, Corpo Místico de Cristo: "disso, necessariamente se conclui a importância que se há de atribuir ao canto, por manifestar de um modo especial o aspecto eclesial da celebração." ${ }^{6}$

\section{A importância da música na comunidade cristã primitiva}

Da primeira comunidade cristã se diz:

Eram perseverantes em ouvir o ensinamento dos Apóstolos, na comunhão fraterna, no partir do pão e nas orações [...]. Diariamente, todos juntos frequentavam o Templo e nas casas partiam o pão, tomando o alimento com alegria e simplicidade de coração. Louvavam a Deus e eram estimados por todo o povo. E cada dia o Senhor acrescentava à comunidade outras pessoas que iam aceitando a salvação. (At 2).

Enraizados numa tradição mais que milenar, os protagonistas do Novo Testamento, Maria, José, Jesus e os Discípulos, a Comunidade Cristã primitiva, são pessoas que continuam a celebrar sua fé cantando e exultando de alegria. É assim que os Salmos, tão frequentemente, se encontram nos lábios de Jesus e são o livro do Antigo Testamento mais citado nos livros do Novo.

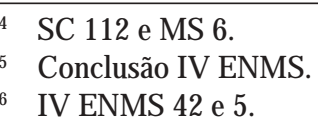


Os numerosos hinos paulinos, que tão apropriadamente ilustram as Cartas do Apóstolo (Ef 1, p. 3-14; 5, 14; Cl 1, p. 12-20; 1Tm 1, 17; 3, 16; 2Tm 2, p. 11-13), valendo destacar os dois hinos cristológicos de Fl 2,6-11 e 1Tm 6, 15-16. O hino batismal de Pedro (1Pd 2). Os hinos e aclamações que ocorrem a cada passo na liturgia celeste descrita na Livro do Apocalipse são, sem dúvida, como que um "retrato cantado" das celebrações das comunidades joaninas. A começar pelo Santo (Ap 4, 8), que, tomado da visão do Profeta Isaías (Is 6,3), já era cantado no culto da Sinagoga e continuava ecoando nas assembléias cristãs, seguem como se fossem um concerto sem fim: Ap 4, 1; 5, 9-10.12.13.14; 6, 10; 7, 10-12; 11, 15. 17-18; 12, 10-12; 15, 3-4; 16, 5-6.7; 19, 1-8... É o cântico novo dos redimidos, a celebrarem com vibração intensa os novos céus e a nova terra, já que, na Páscoa nova do Cordeiro, Deus faz novas todas as coisas (Ap 21, p. 1-5).

\section{A música litúrgica na igreja de hoje}

A primeira e solene palavra do Concílio Vaticano II foi justamente a Constituição sobre a Sagrada Liturgia, datada de 4 de dezembro de 1963. Este importante documento veio antes de tudo reavivar a fé tradicional da Igreja. É neste contexto ideal que devemos situar o canto de nossas Comunidades Cristãs ao celebrarem sua fé e, consequentemente, o exercício dos ministérios musicais. É o mesmo Concílio que, ao constatar que grande parte da participação da assembléia é segurada pela música, pelo canto, percebe e proclama que a música, o canto litúrgico, não são apenas "enfeite", mas fazem parte necessária ou integrante da liturgia solene.

A partir do Concílio Vaticano II, algumas intuições e critérios vão inspirando e provocando providencialmente toda uma renovação da música litúrgica: ${ }^{7}$

- liturgia é a celebração do Mistério Pascal realizada pelo Povo de Deus; a participação das pessoas, da assembléia, como exercício do novo sacerdócio, com Cristo, por Cristo e em Cristo, é de fundamental importância e constitui valor primordial;

Estudos da IGREJA CATÓLICA Conferência Nacional dos Bispos do Brasil. A música litúrgica no Brasil: Estudos da CNBB 79. São Paulo: Paulus, 1999. 
- canto e música, antes de ser obras codificadas para execução, são gesto vivo, experiência existencial; são vivência simbólica "aqui e agora", antes de ser repertório ao qual as pessoas devam se adaptar;

- canto e música participam da dimensão sacramental da liturgia; são símbolos importantes do Mistério de Cristo e da Igreja, e não ornamento exterior; são encarnações, em estruturas comunicativas, da Palavra, do diálogo salvífico entre as Pessoas Divinas e as pessoas humanas, e não elementos rituais e estéticos de uma religiosidade qualquer;

- canto e música, no contexto da ação litúrgica, não são realidades autônomas, mas funcionais; estão aí a serviço do Mistério da Fé, da assembléia sacerdotal. Artistas e demais atores se empenharão em encontrar a expressão musical mais bela e adequada, levando em conta o rito e as pessoas que vão executá-lo. O que deve prevalecer não são os gostos, a estética individual de cada um, mas a essencialidade do Mistério e a participação frutuosa e prazerosa de todos. Os agentes litúrgico-musicais desempenharão tanto melhor o seu papel quanto melhores intérpretes forem da fé, da vida e do jeito de ser da sua gente;

- canto e música, partindo de bases antropológicas e do universo cultural de quem crê, devem possibilitar a expressão verdadeira da assembléia, bem como a autenticidade de sua participação. A beleza das formas é necessária, mas não é mensurável unicamente a partir de normas jurídicas ou estéticas;

- os repertórios do passado e as novas criações não devem ser vistos como bens culturais, ostentados para dar prestígio à instituição ou embelezar suas cerimônias, mas como subsídios simbólicos a ser aproveitados por comunidades concretas, de forma realmente significativa e participativa. 


\section{O canto litúrgico enraizado na assembléia}

A renovação litúrgica do Vaticano II tem sua principal razão de ser na participação do povo de Deus no mistério de Salvação que se realiza na liturgia. Como decorrência da natureza da própria liturgia, "o povo tem o direito e o dever a esta participação". ${ }^{8}$

Todos os ministérios e serviços nascem da comunidade e a ela se destinam para a sua melhor participação e crescimento espiritual e a "edificação do Corpo de Cristo". ${ }^{9}$ Toda liturgia autêntica revela a própria Igreja e sua índole hierárquica e comunitária, e requer uma participação ativa de todos os seus membros, de acordo com a sua função. "Disso necessariamente se conclui a importância que se há de atribuir ao canto, por manifestar de modo especial o aspecto eclesial da celebração". ${ }^{10}$

Seguindo essa dinâmica de ação comunitária, lugar de destaque merece o coro litúrgico. Quanto a esse, a renovação litúrgica deu-lhe um papel de destaque na celebração da liturgia. O coro deve, porém, renovar-se com a liturgia em seu modo de ser, de atuar, em seu repertório, estilo formação e mentalidade. Ele desempenha um verdadeiro ministério ${ }^{11}$ ou função litúrgica na assembléia celebrante, e por isso é hoje, mais do que nunca, indispensável a uma celebração viva na liturgia renovada, e sua atuação redunda em benefício da própria comunidade, principalmente:

a) pela valorização da liturgia cantada, que deve ser o modelo das demais celebrações;

b) pela insistência em se observar exatamente o sentido e a natureza própria de cada rito e canto;

c) pela necessidade de variação nas formas de celebração e de participação;

d) pelo auxílio que presta à participação do povo.

\footnotetext{
SC 14.

Ef 4,14 .

MS 42 e 5.

SC 29.
} 
Pelas mesmas razões, fundamenta-se e recomenda-se o ministério do animador do canto nas comunidades, e mais:

Providencie-se que haja ao menos um ou outro cantor devidamente formado, o qual deve então propor ao povo ao menos as melodias mais simples, para que este participe, e deverá oportunamente dirigir e apoiar os fiéis. Convém que haja tal cantor também nas igrejas que tem coral. ${ }^{12}$

Todos sabemos a importância de um bom ensaiador-animador numa comunidade. É de seu serviço dedicado que depende em grande parte a boa participação cantada do povo.

Os instrumentos musicais podem ser de grande utilidade na liturgia, quer acompanhando o canto, quer sem ele, ${ }^{13}$ na medida em que prestam serviço à palavra cantada, ao rito (explicando-o melhor) e á comunidade em oração; dessa maneira a música instrumental participa da sacralidade da liturgia e tornase música sacra por participação.

O instrumento por si mesmo, como prolongamento da voz humana (alma e voz), não é nem sacro nem profano, assim como a voz humana em si mesma não o é. A classificação de instrumentos em sacros e profanos depende da relação sócio-cultural-psicológica mutável quanto ao tempo (na história) e quanto ao lugar (nas culturas diversas). Se um instrumento consegue integrar-se na liturgia, ajudando-a e exprimindo-a melhor, especialmente pelo acompanhamento do canto, este instrumento tornase sacro, participando da sacralidade da liturgia. ${ }^{14}$

Ainda, para que haja renovação musical, são necessários compositores competentes e imbuídos do espírito de apostolado litúrgico e pastoral, compenetrados de que são chamados para cultivar a música sacra e para alimentarlhe o tesouro. Há que incentivar a composição de "melodias que apresentem as características da verdadeira música sacra, e que possam ser cantadas não só pelos grandes coros [...], mas também por toda comunidade dos fiéis. ${ }^{15}$

Igualmente, "examinem as obras do passado, seus gêneros e características, mas sempre com os olhos atentos se voltem para as novas leis e necessidades da sagrada liturgia...." ${ }^{16}$ pois, a adaptação da Música Sacra naquelas

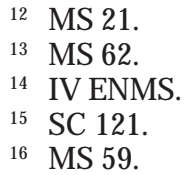


regiões dotadas de tradição musical própria, principalmente nas regiões missionárias, ${ }^{17}$ exigirá dos peritos preparação toda especial. Os que a esta tarefa se dedicam devem possuir suficiente conhecimento, não só da liturgia e da tradição musical da Igreja, como também da língua, do canto popular e de outras expressões do gênio do povo para o qual trabalham. ${ }^{18}$

\section{A natureza sacramental da música litúrgica}

Nossas celebrações são memorial e mistério. Recordando, em palavras e gestos, os fatos salvíficos do passado, a assembléia celebrante goza da certeza de que o Deus de ontem, o Deus de hoje e de sempre aí está presente. A celebração é o ponto de encontro com o Senhor Ressuscitado. Aí o povo de Deus se renova na certeza de que ele está presente todos os dias, até o fim do mundo. ${ }^{19} \mathrm{~A}$ música, a mais espiritual de todas as artes, tem tudo a ver com essa experiência.

Ser cristão é, sobretudo assumir em sua prática de vida o agir do próprio Cristo, deixar-se conduzir pelo dinamismo criador do seu Espírito, fazer-se instrumento da ação libertadora de Deus,$^{20} \mathrm{o}$ agir de Deus, por Cristo, em nós, dando assim pleno sentido e concretude: ${ }^{21}$

- ao canto que acompanha a procissão das oferendas para a Ceia do Senhor, expressão inicial da entrega de nossas próprias vidas, em Cristo;

- aos Prefácios e Louvações que precedem os gestos sacramentais, culminando no "Santo", momento apoteótico na introdução da Oração eucarística;

- a toda a Oração Eucarística, com seus vários elementos de invocação do Espírito, narração da Ceia e retomada dos gestos de Cristos, rememoração do mistério Pascal e as correspondentes aclamações;

- ao canto do "grande Amém" (doxologia final), cantado por todos;

- ao canto do "Cordeiro", ao repartir o Pão a ser distribuído;

- ao canto de Comunhão, sintonizado com a Liturgia da Palavra, e ao canto após a Comunhão.

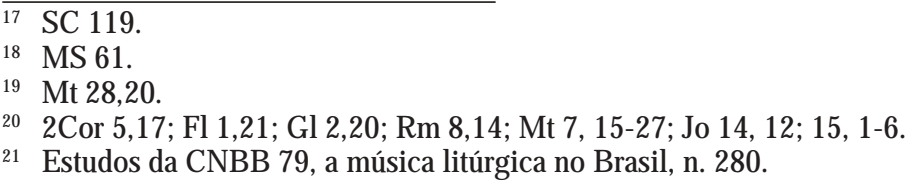




\section{Conclusão}

A história da música litúrgica, como de toda Liturgia, mostra que o resgate as origens é necessário para que a inculturação possa acontecer de maneira verdadeira e coerente. A música é um dos reflexos das mudanças culturais, e ao mesmo tempo ela marca e eterniza os períodos vividos. Como parte da Liturgia, é um dos principais sinais de inculturação. O memorial da paixão, morte e ressurreição de Jesus inspira as mais diversas manifestações artísticas e a música expressa os mais profundos sentimentos sobre esse memorial. A música litúrgica deve surgir também da realidade das comunidades, expressando a compreensão e a resposta das mesmas. Sua constante renovação é fundamental, mas sempre mantendo a harmonia com a Tradição autêntica da Igreja.

\section{Referências}

A BÍBLIA de Jerusalém. 8. ed. São Paulo: Paulinas, 1981.

CONFERÊNCIA NACIONAL DOS BISPOS DO BRASIL - CNBB. A música litúrgica no Brasil: estudos da CNBB 79. São Paulo: Paulus, 1999.

CONCÍLIO ECUMÊNICO VATICANO II. 1962-1965. Sacrosanctum Concilium: constituição sobre a Sagrada Liturgia. 2. ed. Petrópolis, RJ: Vozes, 1966.

PAULO VI. Discurso às Nações Unidas. 4 out. 1965. Disponível em: http:// www.vatican.va/holy_father/paul_vi/speeches/1965/documents/hf_pvi_spe_19651004_united-nations_po.html. Acesso em: 19 nov. 2007.

Recebido: $21 / 02 / 2008$

Received: 02/21/2008

Aprovado: 10/03/2008

Approved: 03/10/2008 